Article

\title{
Tribological Performance of CF-PEEK Sliding against 17-4PH Stainless Steel with Various Cermet Coatings for Water Hydraulic Piston Pump Application
}

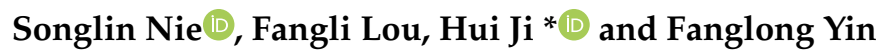 \\ Beijing Key Laboratory of Advanced Manufacturing Technology, Beijing University of Technology, \\ Beijing 100124, China \\ * Correspondence: jihui@bjut.edu.cn; Tel.: +86-10-6739-6362; Fax: +86-10-6739-1617
}

Received: 19 June 2019; Accepted: 5 July 2019; Published: 11 July 2019

\begin{abstract}
To improve the abrasion resistance performance of the critical tribopairs within water hydraulic piston pumps, tribological characteristics of the stainless steel 17-4PH and $17-4 \mathrm{PH}$ coated with $\mathrm{Cr}_{3} \mathrm{C}_{2}-\mathrm{NiCr}$, WC-10Co- $4 \mathrm{Cr}, \mathrm{Cr}_{2} \mathrm{O}_{3}$ and $\mathrm{Al}_{2} \mathrm{O}_{3}-13 \% \mathrm{TiO}_{2}$ sliding against carbon fiber reinforced polyetheretherketone (CF-PEEK) composite under water-lubricated condition were experimentally studied using a pin-on-ring test bench with different working conditions. It has been demonstrated by the experimental results that the tribological behaviors of CF-PEEK/cermet coatings tribipairs were better than that of CF-PEEK/17-4PH tribopair under water lubrication. However, the $\mathrm{Cr}_{3} \mathrm{C}_{2}-\mathrm{NiCr}$ coating could be damaged under high rotational speed. Due to the reaction film produced by the $\mathrm{Al}_{2} \mathrm{O}_{3}-13 \% \mathrm{TiO}_{2}$ and water, the $\mathrm{CF}-\mathrm{PEEK} / \mathrm{Al}_{2} \mathrm{O}_{3}-13 \% \mathrm{TiO}_{2}$ material combination exhibits more excellent tribological behaviors than other tribopairs lubricated with water, and could preferentially be used in water hydraulic piston pumps.
\end{abstract}

Keywords: tribological performance; cermet coating; CF-PEEK; water lubrication

\section{Introduction}

Water hydraulic power transmission has been widely used in the food processing industry, chemical and pharmaceutical industry, water mist fire extinguishing and seawater reverse osmosis desalination system due to its environmental friendliness, cleanliness of working media, low operation cost and high efficiency [1-5]. Figure 1 illustrates the structure of a water hydraulic axial piston pump (WHAPP), which is a critical power component of water hydraulic transmission system. It should be noted that all of the tribopairs in WHAPP are directly lubricated with water. Therefore, there are some challenging problems in the development of high-reliability WHAPPs. For example, the bad lubrication, strong corrosiveness and low viscosity of water could lead to early failure of the critical tribopairs (such as the slipper/swash-plate, sliding bearing/cylinder, piston/cylinder, valve-plate/port-plate tribopairs) in WHAPP (as shown in Figure 1) [6]. Consequently, the use of materials of the critical tribopairs in WHAPP with low friction and resistant to wear underwater lubrication condition is important. 


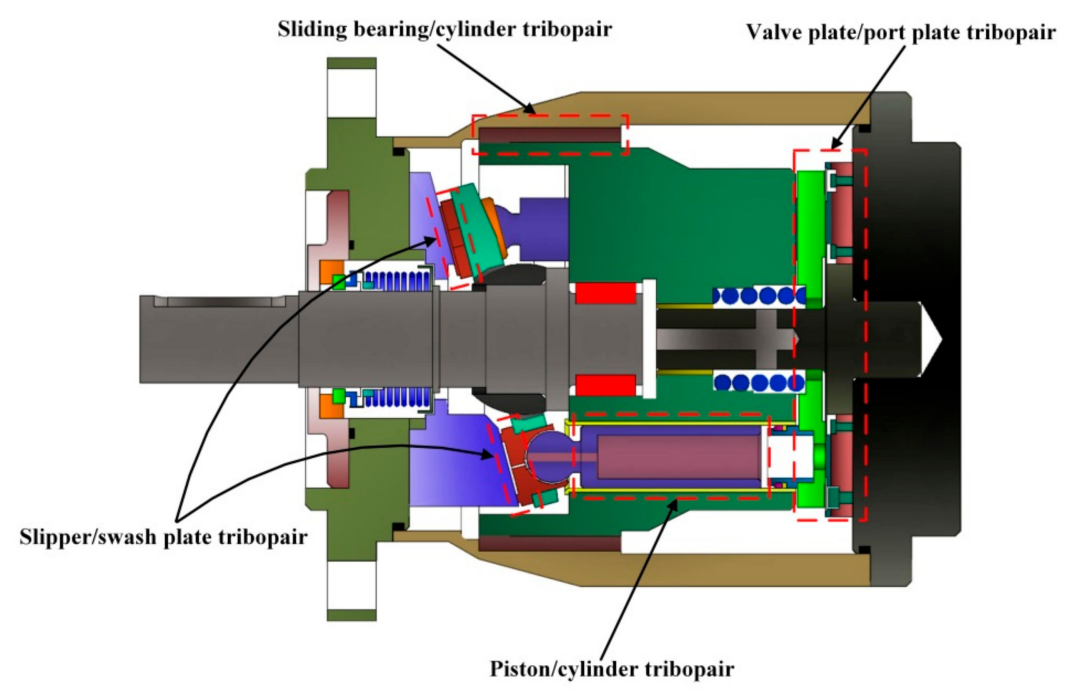

Figure 1. Configurations of a water hydraulic axial piston pump.

The tribopairs consisting of stainless steel and reinforced polymer PEEK have been applied successfully in the water hydraulic components with medium-high pressure (working pressure less than $16 \mathrm{MPa}$ ) [7]. However, when using this material combination, the working water medium should be filtered through a high precision filter with $10 \mu \mathrm{m}$ absolute filtering accuracy. This is due to the fact that the stainless steel is not the best material for water hydraulic pumps to overcome friction and wear because of its relatively low hardness (lower than HRC 50) [8]. Fortunately, several reports have demonstrated that cermet and ceramic coatings have excellent tribological characteristics especially lubricated with air, oil and water [9-11]. Huang et al. [12] researched the friction and wear properties of $\mathrm{Ti}(\mathrm{C}, \mathrm{N})$ cermet coupled with $\mathrm{Si}_{3} \mathrm{~N}_{4}$ engineering ceramic lubricated with water. It is demonstrated that super-low friction coefficient can be detected with a $2 \mathrm{~N}$ applied load. Wu et al. [13] studied the tribological performance of $\mathrm{WC}-10 \mathrm{Co}-4 \mathrm{Cr}$ coating sliding against $\mathrm{Si}_{3} \mathrm{~N}_{4}$ lubricated with silt-laden water. It was concluded that the deposition of $\mathrm{SiO}_{2}$ and $\mathrm{Si}(\mathrm{OH})_{4}$ layers produced by the tribo-chemical reaction between water and $\mathrm{Si}_{3} \mathrm{~N}_{4}$ can significantly reduce the friction and wear of the friction pair. In other research [14], they investigated the tribological characteristics of different mass ratio $\mathrm{Al}_{2} \mathrm{O}_{3}-13 \% \mathrm{TiO}_{2}$ coatings coupled with $\mathrm{Si}_{3} \mathrm{~N}_{4}$ lubricated with water. It has been demonstrated that the material combination of $\mathrm{Al}_{2} \mathrm{O}_{3}-13 \% \mathrm{TiO}_{2} / \mathrm{Si}_{3} \mathrm{~N}_{4}$ is an appropriate scheme to use in water hydraulic components. Wang et al. [15] studied the friction and characteristics of $\mathrm{Cr} /$ graphite-like carbon (GLC) coating coupled with $\mathrm{Al}_{2} \mathrm{O}_{3}, \mathrm{ZrO}_{2}, \mathrm{SiC}, \mathrm{Si}_{3} \mathrm{~N}_{4}$ and WC under seawater lubrication condition. It was found that the combination of $\mathrm{Cr} / \mathrm{GLC}$ coating and $\mathrm{Si}_{3} \mathrm{~N}_{4}$ ceramic presented the optimum tribological performance. Strmčnik et al. [16] presented an investigation on the tribological behaviors of AISI 440C ball coupled with diamond-like carbon (DLC) coated disk under water lubrication condition for orbital hydraulic motor application. It was concluded that the wear coefficient for the DLC coating was about $10^{-9} \mathrm{~mm}^{3} / \mathrm{Nm}$, and the friction coefficient of this tribopair in water was lower than that under oil lubrication conditions. Qiu et al. [17] comparatively researched the wear properties of different material combinations of $316 \mathrm{~L}$, surface treatment $316 \mathrm{~L}$, and PEEK with $30 \%$ carbon fiber in water. It has been demonstrated that the combination of 316L with surface treatment of tetrahedral amorphous carbon and PEEK with 30\% carbon fiber presented the optimum friction characteristics. Zhu et al. [18] concluded that the tribological performance of $\mathrm{Ni}_{3} \mathrm{Al}-\mathrm{Ag} / \mathrm{Al}_{2} \mathrm{O}_{3}$ tribopair is better than that of $\mathrm{SiC} / 316 \mathrm{~L}$ tribopair in a seawater environment. Therefore, coating the stainless steel with cermet and engineering ceramic may be an effective way to improve the abrasion resistance performance of the tribopairs in WHAPP. In addition, carbon fiber reinforced polyetheretherketone (CF-PEEK) has excellent wear-resistance and tribological behaviors in water. And the friction and wear properties of CF-PEEK coupled with 17-4PH stainless steel have been comprehensively investigated [19-22]. The experimental results indicated that 
the tribological performance of CF-PEEK mating with17-4PH stainless steel in seawater is excellent, which can be used in high-pressure seawater hydraulic components.

Though several papers are available on tribology of cermet/engineering ceramic and PEEK/stainless steel tribopairs in water, adequate data are not available on the tribological performance of CF-PEEK coupled with different cermet coatings for WHAPP application. Therefore, in this paper, several kinds of cermet coatings have been manufactured by using high-velocity oxygen-fuel (HVOF) technology. A comparative study on the friction and wear properties of the CF-PEEK coupled with 17-4PH stainless steel, $\mathrm{Cr}_{3} \mathrm{C}_{2}-\mathrm{NiCr}$, WC- $10 \mathrm{Co}-4 \mathrm{Cr}, \mathrm{Cr}_{2} \mathrm{O}_{3}$ and $\mathrm{Al}_{2} \mathrm{O}_{3}-13 \% \mathrm{TiO}_{2}$ coatings will be conducted underwater lubrication condition.

\section{Experiments}

\subsection{Specimens Introduction}

The upper pin was made of CF-PEEK and contained 30\% volume fraction of carbon fiber, polytetrafluoroethylene and graphite formed through hot-pressing, sintering and molding technology [22]. The physical properties of CF-PEEK composite are shown in Table 1. The lower disk was made of $17-4 \mathrm{PH}$ stainless steel, and the surface hardness of the lower specimens was improved by solution and aging treatment before being sprayed (the hardness of $17-4 \mathrm{PH}$ is about HRC 45). Then, several cermet coatings were sprayed on the surface of $17-4 \mathrm{PH}$ stainless steel using the HVOF technique respectively. Table 2 lists the main chemical contents of $17-4 \mathrm{PH}$ stainless steel. In addition, the major physical performance parameters of the cermet coatings are shown in Table 3. Before each tribological test, the contacting surface roughness of the CF-PEEK and cermet coatings specimens was approximately $0.1 \mu \mathrm{m}$ by grinding, diamond anti-scuffing paste polishing and metallographic sandpaper. Furthermore, all the upper pins and lower disks were immersed in water for more than $168 \mathrm{~h}$ to remove the influence of water absorption on the weight of the specimens during the tribological test.

Table 1. Main physical properties of carbon fiber reinforced polyetheretherketone (CF-PEEK) composite.

\begin{tabular}{cccc}
\hline Property & Standard & Unit & Value \\
\hline Density & ISO 1183 & $\mathrm{g} / \mathrm{cm}^{3}$ & 1.44 \\
Water Absorption $\left(24 \mathrm{~h}, 23^{\circ} \mathrm{C}\right)$ & ISO 62 & $\%$ & 0.06 \\
Rockwell Hardness & ASTM D785 & - & 102 \\
Tensile Strength $\left(23^{\circ} \mathrm{C}\right)$ & ASTM D638 & $\mathrm{MPa}$ & 134 \\
Bending Strength $\left(23^{\circ} \mathrm{C}\right)$ & ASTM D790 & $\mathrm{MPa}$ & 186 \\
Compressive Strength $\left(23^{\circ} \mathrm{C}\right)$ & ASTM D695 & $\mathrm{MPa}$ & 150 \\
Coefficient of Thermal Expansion & ASTM D696 & $10^{-5} /{ }^{\circ} \mathrm{C}$ & 2.2 \\
\hline
\end{tabular}

Table 2. Main chemical contents of $17-4 \mathrm{PH}$ stainless steel (wt.\%).

\begin{tabular}{cccccc}
\hline $\mathbf{C}$ & $\mathbf{S i}$ & $\mathbf{M n}$ & $\mathbf{P}$ & $\mathbf{C r}$ & $\mathbf{N i}$ \\
\hline$\leq 0.07$ & $\leq 1.00$ & $\leq 1.00$ & $\leq 0.035$ & $15.5-17.5$ & $3.0-5.0$ \\
\hline
\end{tabular}

Table 3. Main physical performance of $\mathrm{Cr}_{3} \mathrm{C}_{2}-\mathrm{NiCr}$, WC- $10 \mathrm{Co}-4 \mathrm{Cr}, \mathrm{Cr}_{2} \mathrm{O}_{3}$ and $\mathrm{Al}_{2} \mathrm{O}_{3}-13 \% \mathrm{TiO}_{2}$ coatings.

\begin{tabular}{ccccc}
\hline Property & $\mathrm{Cr}_{\mathbf{3}} \mathbf{C}_{\mathbf{2}}$ - $\mathbf{N i C r}$ & WC-10Co-4Cr & $\mathbf{C r}_{\mathbf{2}} \mathbf{O}_{\mathbf{3}}$ & $\mathbf{A l}_{\mathbf{2}} \mathbf{O}_{\mathbf{3}} \mathbf{- 1 3} \mathbf{- 1} \mathbf{T i O}_{\mathbf{2}}$ \\
\hline Density $\left(\mathrm{g} / \mathrm{cm}^{3}\right)$ & 5.92 & 5.40 & 5.21 & 3.6 \\
Vickers Hardness (HV 0.3) & 890 & 1300 & 1620 & 840 \\
Elasticity Modulus (GPa) & 60 & 150 & 75 & 170 \\
Bending Strength (MPa) & 126 & 113 & 132 & 23.5 \\
\hline
\end{tabular}




\subsection{Test Rig and Methods}

The tribological tests were performed in a rotational friction tester (UMT TriboLab, Bruker, Billerica, MA, USA) using pin-on-disk mode (as shown in Figure 2). The UMT TriboLab (version 1.143) applied a programmable load downward by a servo-driven carriage. In addition the two-dimensional force sensor (Bruker, Billerica, MA, USA) (up to $200 \mathrm{~N}$ load) was used to detect the sliding and frictional force between the material combination. During the tests, the lower disk was rotational whereas the upper pin was always stationary. Moreover, a specially designed recirculating liquid holder was provided for testing surfaces immersed in water. The fluid recirculated naturally as the motion of the test surface forced the fluid through apertures in a specially designed chamber and then back to the top of the specimens.
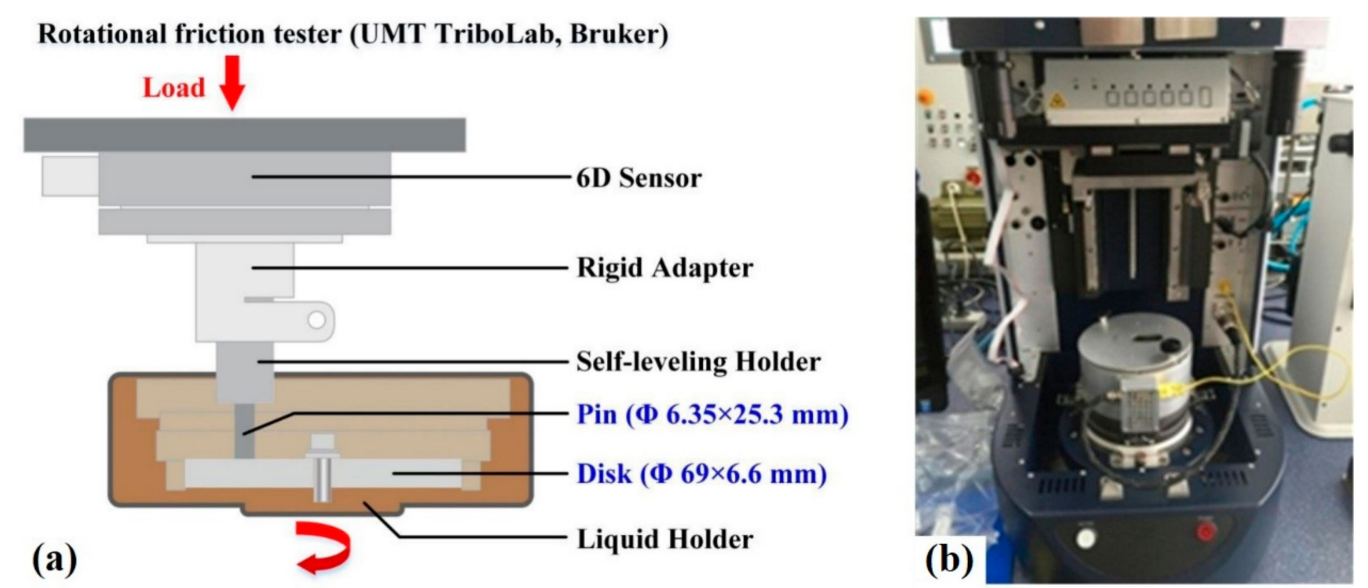

Figure 2. Schematic configuration of the pin-on-disk test: (a) schematic diagram; (b) real photo.

The tests were conducted at a load of $100 \mathrm{~N}$, rotational speeds of 100 and $300 \mathrm{r} / \mathrm{min}$, ambient temperature, and the time for each tribological test was $60 \mathrm{~min}$. Due to the limitation of the test operating condition, the experimental parameters of this research were lower than the real working load and velocity of the tribopairs in WHAPP under the operating pressure of $14 \mathrm{MPa}$. However, the pin-to-disk contacting model was similar to the slipper/swash-plate and valve-plate/port-plate tribopairs, and the tribological tests can also compare the advantages and disadvantages of the proposed material combinations, providing a basis for the material matching of WHAPP. Before and after each test, all the specimens were ultrasonicllay cleaned in anhydrous alcohol and dried with hot air. Then, the weight loss $\Delta m$ can be obtained by the electronic balance (Ohaus CP214, Parsippany, NJ, USA) with an accuracy of $0.1 \mathrm{mg}$. The wear rate $W_{s}$ can be obtained as follows:

$$
W_{s}=\frac{\Delta m}{\rho F_{\mathrm{N}} L}\left(\mathrm{~mm}^{3} / \mathrm{Nm}\right)
$$

where $\rho$ represents the density of the specimens, $F_{N}$ is the applied load, $L$ is the total sliding distance. During the tribological test, the software of UMT TriboLab can collect the dynamic friction coefficient of the tribopairs and other data in real-time. Each test was repeated at least three times for eliminating occasionality of the experimental results under the same working conditions.

To reveal the friction and wear mechanism of the tribopairs, the surface morphology of the CF-PEEK pin and the coupled disk were analyzed by a scanning electron microscope (SEM, SU3500, Hitachi, Tokyo, Japan) equipped with energy dispersive spectroscopy (EDS, EDAX, Berwyn, IL, USA). And a digital microscope (VHX-5000, Keyence, Osaka, Japan) was employed to examine the 3D topographies of the wear track. 


\section{Results and Discussion}

\subsection{Friction and Wear Behavior}

Friction coefficients of CF-PEEK composite coupled with several cermet coatings in water under $100 \mathrm{~N}$ load and $100 \mathrm{r} / \mathrm{min}, 300 \mathrm{r} / \mathrm{min}$ rotational speeds are shown in Figure 3. It is illustrated in Figure 3 that the friction coefficient of each tribopair increased firstly, then decreased slightly, and finally achieved a stable value after experiencing the running-in process. When sliding at $100 \mathrm{r} / \mathrm{min}$, the CF-PEEK/WC-10Co-4Cr tribopair did not operate steadily. Nevertheless, the friction coefficients of other tribopairs awere rapidly stable after a short running-in process under both 100 and $300 \mathrm{r} / \mathrm{min}$. By comparing Figure $3 \mathrm{a}, \mathrm{b}$, it was observed that the friction coefficients of all the tribopairs decreased when the rotational speed increased from 100 to $300 \mathrm{r} / \mathrm{min}$. It can be seen from Figure $3 \mathrm{c}$ that the mean friction coefficients of the tested five material combinations with two rotational speeds are below 0.2. As sliding under $100 \mathrm{r} / \mathrm{min}$ rotational speed, the friction coefficient of $\mathrm{Cr}_{2} \mathrm{O}_{3}$ was almost equal to 0.17 , which was higher than those of other tribopairs. As the rotational speed increased to $300 \mathrm{r} / \mathrm{min}$, the mean friction coefficients of $17-4 \mathrm{PH}$ stainless steel, $\mathrm{Cr}_{3} \mathrm{C}_{2}-\mathrm{NiCr}$, WC-10Co-4Cr, $\mathrm{Cr}_{2} \mathrm{O}_{3}$ and $\mathrm{Al}_{2} \mathrm{O}_{3}-13 \% \mathrm{TiO}_{2}$ coatings reduced to $0.133,0.155,0.135$ and 0.097 respectively. The above experimental results clearly demonstrate that the friction coefficient of $\mathrm{Al}_{2} \mathrm{O}_{3}-13 \% \mathrm{TiO}_{2}$ was lower than those of other tribopairs under high rotational speed.
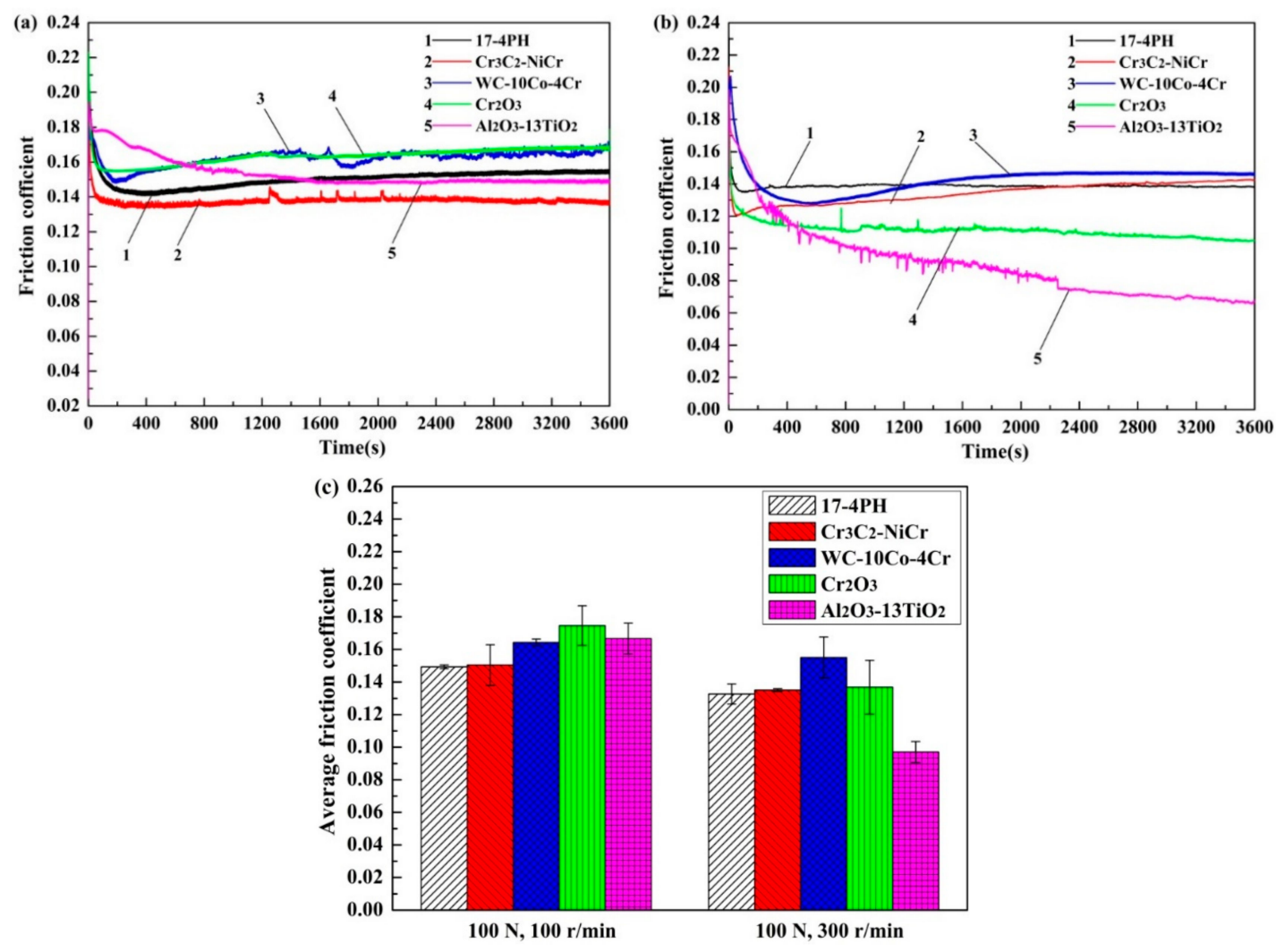

Figure 3. Friction coefficients of $17-4 \mathrm{PH}$ and several coatings sliding against CF-PEEK: (a) $100 \mathrm{~N}$, $100 \mathrm{r} / \mathrm{min}$; (b) $100 \mathrm{~N}, 300 \mathrm{r} / \mathrm{min}$ and (c) the mean friction coefficients.

The wear rates of the CF-PEEK composite, 17-4PH stainless steel and cermet coatings are shown in Figure 4. It should be noted from Figure 4a that the wear rates of CF-PEEK/cermet coatings tribopairs were lower than that of CF-PEEK/17-4PH tribopair. As clearly presented in Figure $4 \mathrm{a}$, the wear rate of CF-PEEK was lowest when sliding against $\mathrm{Al}_{2} \mathrm{O}_{3}-13 \% \mathrm{TiO}_{2}$ coating. When the rotational speed increased from 100 to $300 \mathrm{r} / \mathrm{min}$, the wear rate of CF-PEEK composites had a similar trend with that of the friction coefficient. Additionally, it is clearly illustrated in Figure $4 a, b$ that the wear rates of 
CF-PEEK composites were much higher than those of 17-4PH stainless steel. Furthermore, the cermet coatings exhibited negative wear rates under $100 \mathrm{~N}$ and $300 \mathrm{r} / \mathrm{min}$, so it is inferred that some CF-PEEK composites were transferred to the coating surface. However, the wear rate of $\mathrm{Cr}_{3} \mathrm{C}_{2}-\mathrm{NiCr}$ coating was higher than those of 17-4PH and other cermet coatings, which may be attributed to the damage and spalling of the $\mathrm{Cr}_{3} \mathrm{C}_{2}-\mathrm{NiCr}$ coating under high rotational speed.
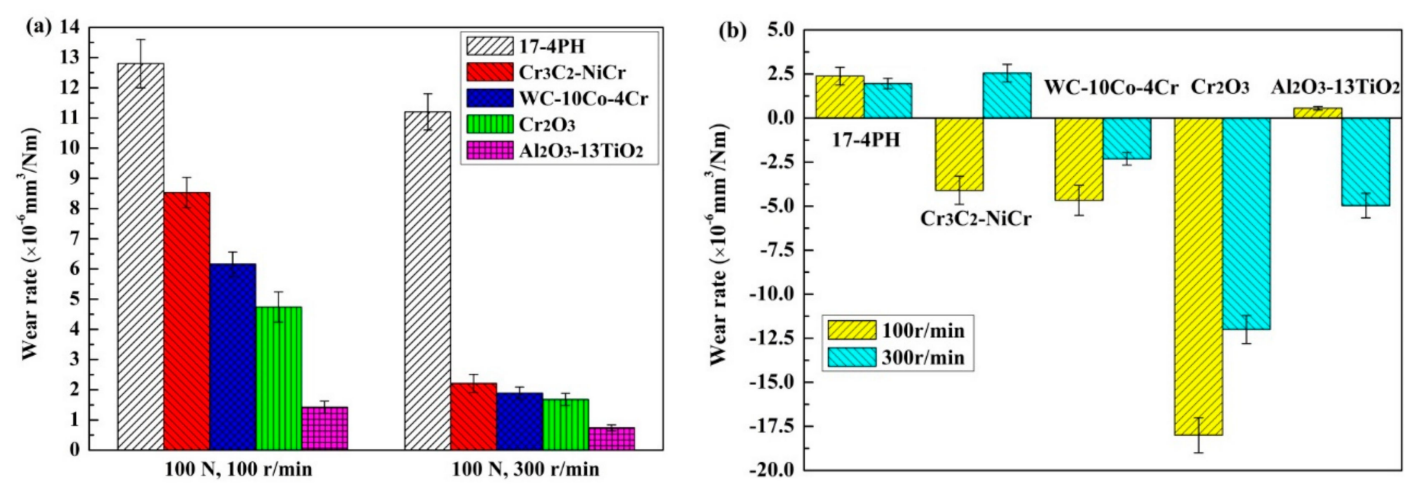

Figure 4. The wear rates of several tribopairs: (a) wear rates of CF-PEEK polymers and (b) wear rates of $17-4 \mathrm{PH}$ and several cermet coatings.

As a result, it can be concluded that the $17-4 \mathrm{PH}$ and cermet coatings presented better friction and wear behavior under a rotational speed of $300 \mathrm{r} / \mathrm{min}$ than $100 \mathrm{r} / \mathrm{min}$. Moreover, the CF-PEEK/ $/ \mathrm{Al}_{2} \mathrm{O}_{3}-13 \% \mathrm{TiO}_{2}$ coating tribopair exhibited better tribological performance in terms of wear than other tribopairs lubricated with water.

\subsection{Analyses of the Worn Surfaces Lubricated with Water}

Figure 5 shows SEM images of CF-PEEK composites against 17-4PH stainless steel and four kinds of cermet coatings at the $100 \mathrm{~N}$ applied load and $300 \mathrm{r} / \mathrm{min}$ rotational speed lubricated with water. It can easily be seen that the worn surface of CF-PEEK/ $/ \mathrm{Al}_{2} \mathrm{O}_{3}-13 \% \mathrm{TiO}_{2}$ tribopair is smoothest, and only a spot of CF-PEEK debris can be observed (Figure 5e). As illustrated in Figure 5a,b, some carbon fibers were exposed to the contacting surface as a result of abrasive wear and slight adhesion wear. When sliding against WC-10Co-4Cr, it can be seen from Figure $5 \mathrm{c}$ that the CF-PEEK contacting surface was characterized by severe plastic deformation and partly broken due to the grinding process. As shown in Figure 5d, CF-PEEK exhibited serious adhesion wear for the $\mathrm{Cr}_{2} \mathrm{O}_{3}$ coating, and large patches of deformed layers (caused by softened matrix material) covered the worn surface, which caused some CF-PEEK composites to tear apart. This is related to the relatively high surface hardness of $\mathrm{Cr}_{2} \mathrm{O}_{3}$ coating (about $1620 \mathrm{Hv}$ ) compared to those of $17-4 \mathrm{PH}$ and other cermet coatings, which could lead to the severe wear of the soft CF-PEEK composite. Therefore, it can be concluded that the large hardness difference between the CF-PEEK and cermet coatings could accelerate the wear of the soft CF-PEEK.
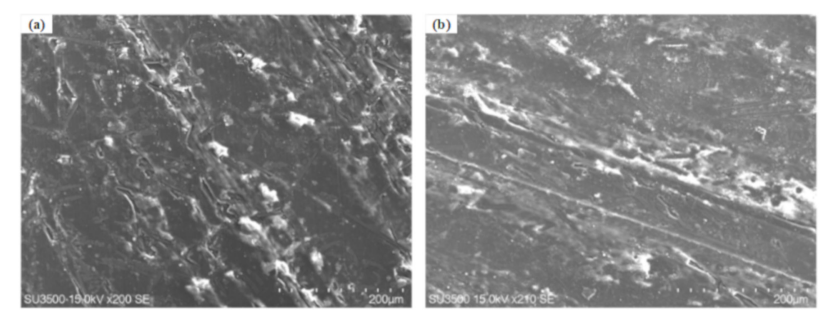

Figure 5. Cont. 


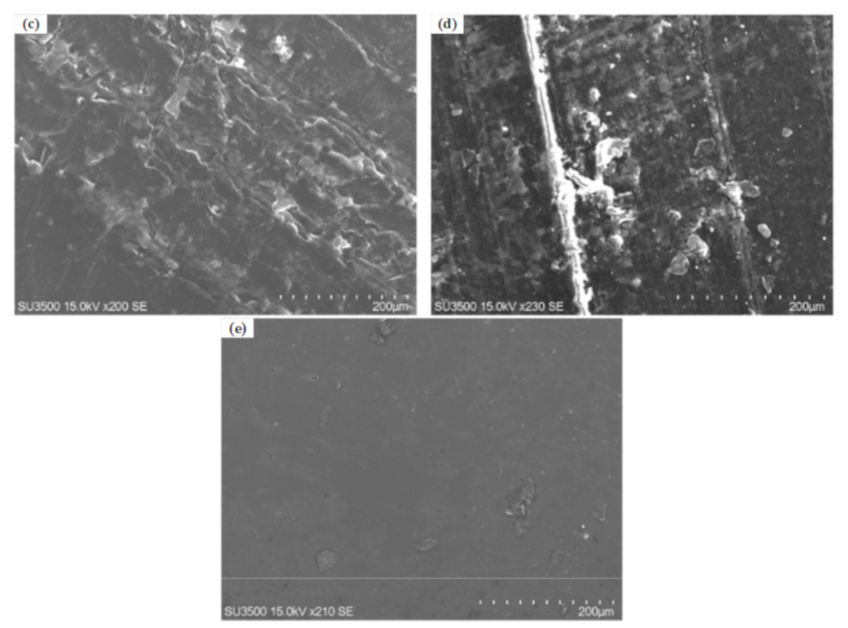

Figure 5. Worn surfaces morphology of CF-PEEK when sliding against $17-4 \mathrm{PH}$ and several cermet coatings (100 N, 300 r/min): (a) CF-PEEK/17-4PH; (b) CF-PEEK/Cr ${ }_{3} \mathrm{C}_{2}-\mathrm{NiCr}$; (c) CF-PEEK/WC-10Co-4Cr; (d) CF-PEEK/Cr ${ }_{2} \mathrm{O}_{3}$ and (e) CF-PEEK/ $/ \mathrm{Al}_{2} \mathrm{O}_{3}-13 \% \mathrm{TiO}_{2}$.

Figure 6 demonstrates the worn surface morphology and EDS data of 17-4PH stainless steel, $\mathrm{Cr}_{3} \mathrm{C}_{2}-\mathrm{NiCr}$, WC $-10 \mathrm{Co}-4 \mathrm{Cr}, \mathrm{Cr}_{2} \mathrm{O}_{3}$ and $\mathrm{Al}_{2} \mathrm{O}_{3}-13 \% \mathrm{TiO}_{2}$ coatings under $100 \mathrm{~N}$ and $300 \mathrm{r} / \mathrm{min}$. It is evident from Figure $6 \mathrm{a}-\mathrm{c}$ that some wear scratches existed on the contacting surfaces owing to the sliding friction along the circumferential direction. As illustrated in Figure 6a, the 17-4PH worn surface mainly contained abrasion marks characterized as deep furrows produced by ploughing processes, and some black wear debris was embedded in the wear track. The corresponding EDS analysis of 17-4PH surface displayed that the wear debris mainly contained $\mathrm{Fe}, \mathrm{Cr}$ and $\mathrm{C}$ elements. Moreover, the detected content of $\mathrm{C}$ element from Figure $6 \mathrm{a}$ was more than that of original 17-4PH stainless steel (as listed in Table 2). This indicates that some elements transferred from the CF-PEEK surface to the 17-4PH surface during the tribological test. In Figure $6 \mathrm{~b}$, some wear debris and shallow furrows appeared on the surface of $\mathrm{Cr}_{3} \mathrm{C}_{2}$-NiCr coating. In addition, it should be noted in Figure $6 \mathrm{~b}$ that the surface of $\mathrm{Cr}_{3} \mathrm{C}_{2}-\mathrm{NiCr}$ coating was slightly rough and characterized with some spalling pits, suggesting the damage and spalling of the $\mathrm{Cr}_{3} \mathrm{C}_{2}-\mathrm{NiCr}$ coating under $100 \mathrm{~N}$ and $300 \mathrm{r} / \mathrm{min}$. Besides, the detected content of $C$ element also demonstrated the transfer of CF-PEEK to the surface of the $\mathrm{Cr}_{3} \mathrm{C}_{2}-\mathrm{NiCr}$ coating. As illustrated in Figure $6 c$, some tiny scratches and wear debris can be found on the pretty smooth worn surface of WC-10Co-4Cr. However, it can be seen from Figure $6 \mathrm{~d}$,e that the wear surfaces of $\mathrm{Cr}_{2} \mathrm{O}_{3}$ and $\mathrm{Al}_{2} \mathrm{O}_{3}$ coatings were characterized by the micropores instead of wear furrows, and no indication of adhesive wear was found. It is inferred the water inside the micropores was instrumental in improving the lubrication and heat dissipation conditions. In the comparison of Figure $6 \mathrm{~d}$,e, one disparity was noticeable that more micropores and sporadic wear debris appeared on $\mathrm{Cr}_{2} \mathrm{O}_{3}$ coating worn surface, which is consistent with the results of negative wear rates of $\mathrm{Cr}_{2} \mathrm{O}_{3}$ coating in Figure 4 . In addition, this indicated that more $\mathrm{Cr}_{2} \mathrm{O}_{3}$ coating and CF-PEEK particles pell off during the sliding process, and then the contacting surface roughness would be increased as well as the friction coefficient of this material combination. Moreover, it is interesting to note from Figure 6 that the content of $\mathrm{C}$ element on $\mathrm{Al}_{2} \mathrm{O}_{3}-13 \% \mathrm{TiO}_{2}$ surface was the smallest among those of the lower specimens. This indicates that the minimum wear-loss and transfer of CF-PEEK could be obtained when sliding against $\mathrm{Al}_{2} \mathrm{O}_{3}-13 \% \mathrm{TiO}_{2}$ coating, which is in agreement with the results of wear rates in Figure $4 \mathrm{a}$. 


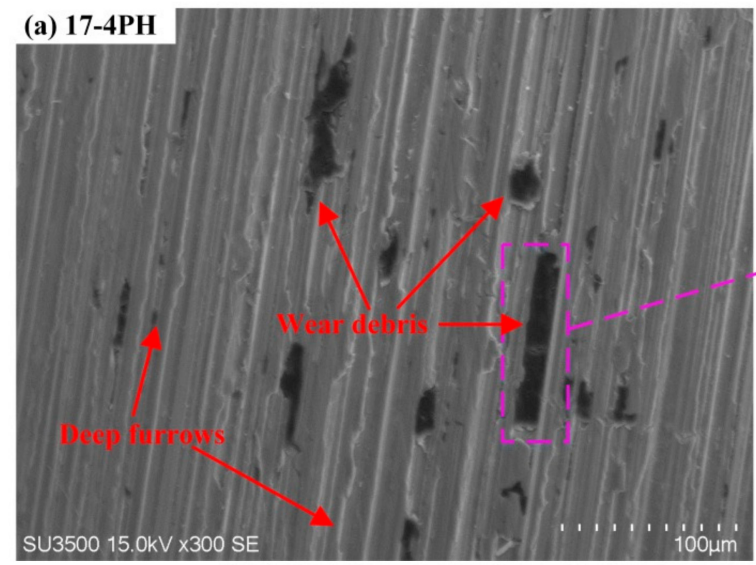

\begin{tabular}{|c|c|c|c|c|c|c|c|}
\hline Elt. & Line & $\begin{array}{c}\text { Intensity } \\
(\mathbf{c} / \mathbf{s})\end{array}$ & Conc & Units & $\begin{array}{c}\text { Error } \\
\text { 2-sig }\end{array}$ & $\begin{array}{c}\text { MDL } \\
\text { 3-sig }\end{array}$ & \\
\hline $\mathrm{C}$ & $\mathrm{Ka}$ & 70.93 & 10.756 & wt.\% & 0.420 & 0.398 & \\
\hline $\mathrm{O}$ & $\mathrm{Ka}$ & 35.45 & 3.228 & wt.\% & 0.200 & 0.218 & \\
\hline $\mathrm{Cr}$ & $\mathrm{Ka}$ & 143.84 & 12.877 & wt.\% & 0.306 & 0.200 & \\
\hline $\mathrm{Fe}$ & $\mathrm{Ka}$ & 361.81 & 54.719 & wt.\% & 0.771 & 0.316 & \\
\hline $\mathrm{Ni}$ & $\mathrm{Ka}$ & 12.62 & 3.121 & wt.\% & 0.356 & 0.420 & \\
\hline $\mathrm{Cu}$ & $\mathrm{Ka}$ & 7.82 & 2.655 & wt.\% & 0.443 & 0.565 & \\
\hline $\mathrm{Nb}$ & $\mathrm{La}$ & 105.64 & 12.645 & wt.\% & 0.402 & 0.378 & \\
\hline & & & 100.000 & wt.\% & & & Total \\
\hline
\end{tabular}

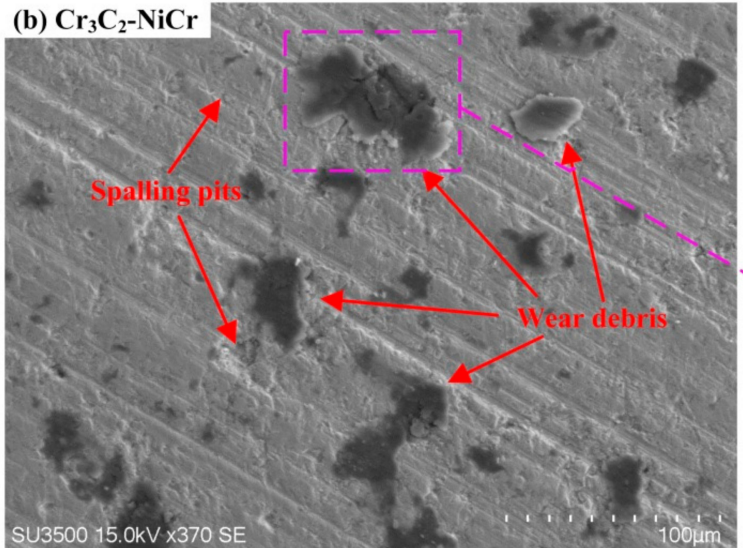

\begin{tabular}{|c|c|c|c|c|c|c|c|}
\hline Elt. & Line & $\begin{array}{c}\text { Intensity } \\
(\mathbf{c} / \mathbf{s})\end{array}$ & Conc & Units & $\begin{array}{c}\text { Error } \\
\text { 2-sig }\end{array}$ & $\begin{array}{c}\text { MDL } \\
\text { 3-sig }\end{array}$ & \\
\hline $\mathrm{C}$ & $\mathrm{Ka}$ & 72.49 & 11.658 & wt.\% & 0.424 & 0.358 & \\
\hline $\mathrm{O}$ & $\mathrm{Ka}$ & 74.39 & 7.861 & wt.\% & 0.268 & 0.196 & \\
\hline $\mathrm{Cr}$ & $\mathrm{Ka}$ & 388.23 & 54.784 & wt.\% & 0.739 & 0.271 & \\
\hline $\mathrm{Ni}$ & $\mathrm{Ka}$ & 51.09 & 17.535 & w..\% & 0.719 & 0.522 & \\
\hline $\mathrm{W}$ & $\mathrm{La}$ & 2.73 & 8.161 & wt.\% & 2.958 & 4.084 & \\
\hline & & & 100.000 & wt.\% & & & Total \\
\hline
\end{tabular}

(c) $\mathrm{WC}-10 \mathrm{Co}-4 \mathrm{Cr}$

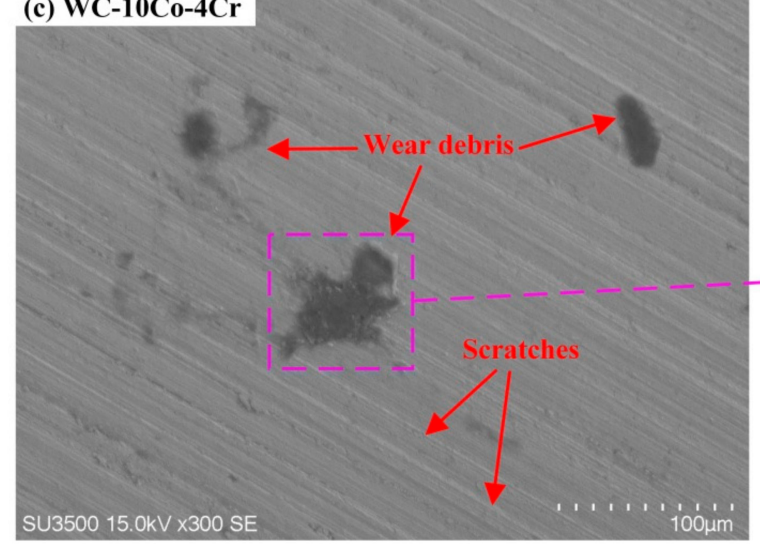

\begin{tabular}{|c|c|c|c|c|c|c|c|}
\hline Elt. & Line & $\begin{array}{c}\text { Intensity } \\
(\mathbf{c} / \mathbf{s})\end{array}$ & Conc & Units & $\begin{array}{c}\text { Error } \\
\text { 2-sig }\end{array}$ & $\begin{array}{c}\text { MDL } \\
\text { 3-sig }\end{array}$ & \\
\hline $\mathrm{C}$ & $\mathrm{Ka}$ & 53.76 & 5.816 & wt.\% & 0.302 & 0.339 & \\
\hline $\mathrm{O}$ & $\mathrm{Ka}$ & 48.08 & 4.285 & wt.\% & 0.218 & 0.227 & \\
\hline $\mathrm{Cl}$ & $\mathrm{Ka}$ & 99.44 & 4.177 & wt.\% & 0.140 & 0.136 & \\
\hline $\mathrm{Cr}$ & $\mathrm{Ka}$ & 37.61 & 2.978 & wt.\% & 0.190 & 0.218 & \\
\hline $\mathrm{Co}$ & $\mathrm{Ka}$ & 46.16 & 6.561 & wt.\% & 0.343 & 0.361 & \\
\hline $\mathrm{W}$ & $\mathrm{La}$ & 51.65 & 76.183 & wt.\% & 3.445 & 3.203 & \\
\hline & & & 100.000 & wt.\% & & & Total \\
\hline
\end{tabular}

Figure 6. Cont. 


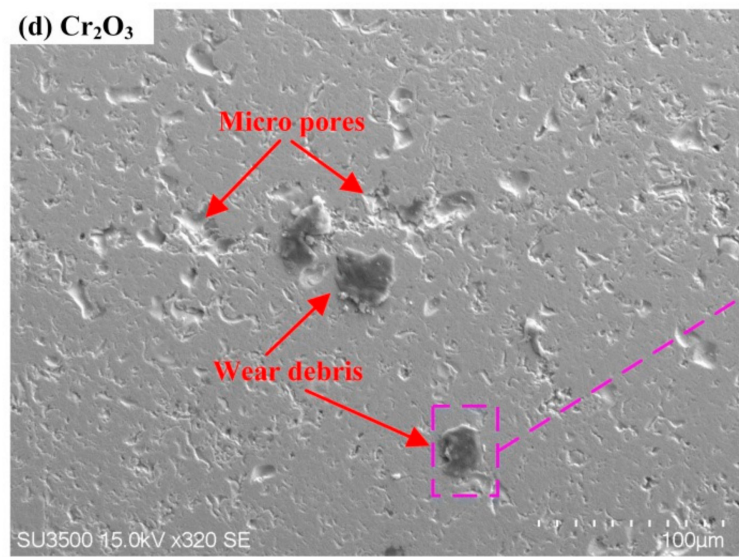

\begin{tabular}{|c|c|c|c|c|c|c|c|}
\hline EIt. & Line & $\begin{array}{c}\text { Intensity } \\
(\mathbf{c} / \mathbf{s})\end{array}$ & Conc & Units & $\begin{array}{c}\text { Error } \\
\text { 2-sig }\end{array}$ & $\begin{array}{c}\text { MDL } \\
\text { 3-sig }\end{array}$ & \\
\hline $\mathrm{C}$ & $\mathrm{Ka}$ & 74.50 & 7.394 & wt.\% & 0.286 & 0.278 & \\
\hline $\mathrm{O}$ & $\mathrm{Ka}$ & 449.67 & 27.005 & wt. $\%$ & 0.340 & 0.134 & \\
\hline $\mathrm{Cr}$ & $\mathrm{Ka}$ & 621.33 & 65.601 & wt.\% & 0.696 & 0.234 & \\
\hline & & & 100.000 & wt. $\%$ & & & Total \\
\hline
\end{tabular}

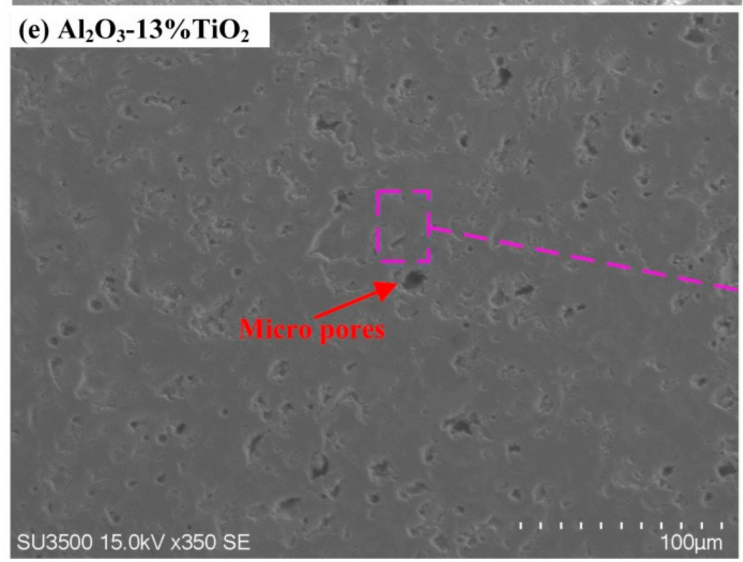

\begin{tabular}{|c|c|c|c|c|c|c|c|}
\hline Elt. & Line & $\begin{array}{c}\text { Intensity } \\
(\mathbf{c} / \mathbf{s})\end{array}$ & Conc & Units & $\begin{array}{c}\text { Error } \\
\text { 2-sig }\end{array}$ & $\begin{array}{c}\text { MDL } \\
\text { 3-sig }\end{array}$ & \\
\hline $\mathrm{C}$ & $\mathrm{Ka}$ & 4.31 & 2.771 & wt.\% & 0.811 & 1.123 & \\
\hline $\mathrm{O}$ & $\mathrm{Ka}$ & 176.88 & 31.561 & wt.\% & 0.650 & 0.331 & \\
\hline $\mathrm{Al}$ & $\mathrm{Ka}$ & 985.84 & 63.971 & wt.\% & 0.536 & 0.161 & \\
\hline $\mathrm{Fe}$ & $\mathrm{Ka}$ & 5.00 & 1.697 & wt.\% & 0.365 & 0.471 & \\
\hline & & & 100.000 & wt.\% & & & Total \\
\hline
\end{tabular}

Figure 6. Worn surfaces morphology and the corresponding EDS results of different cermet coatings (100 N, 300 r/min): (a) 17-4PH; (b) $\mathrm{Cr}_{3} \mathrm{C}_{2}-\mathrm{NiCr}$; (c) WC-10Co-4Cr; (d) $\mathrm{Cr}_{2} \mathrm{O}_{3}$ and (e) $\mathrm{Al}_{2} \mathrm{O}_{3}-13 \% \mathrm{TiO}_{2}$.

\subsection{Wear Track Analysis}

The cross-sectional profiles and corresponding data of wear scar of the 17-4PH and several coatings under $100 \mathrm{~N}$ and $300 \mathrm{r} / \mathrm{min}$ are displayed in Figure 7 and Table 4, respectively. It is clearly shown in Figure $7 \mathrm{a}$ and Table 4 that the depth and width of the wear scar of $17-4 \mathrm{PH}$ were about $40 \mu \mathrm{m}$ and $2.19 \mathrm{~mm}$, respectively, which were higher than those of WC- $10 \mathrm{Co}-4 \mathrm{Cr}, \mathrm{Cr}_{2} \mathrm{O}_{3}$ and $\mathrm{Al}_{2} \mathrm{O}_{3}-13 \% \mathrm{TiO}_{2}$ coatings. This indicates that the WC- $10 \mathrm{Co}-4 \mathrm{Cr}, \mathrm{Cr}_{2} \mathrm{O}_{3}$ and $\mathrm{Al}_{2} \mathrm{O}_{3}-13 \% \mathrm{TiO}_{2}$ coated surfaces were less damaged than the uncoated surface of 17-4PH. However, the wear scar depth and width of the $\mathrm{Cr}_{3} \mathrm{C}_{2}-\mathrm{NiCr}$ coating were higher than other lower specimens. It is inferred that the $\mathrm{Cr}_{3} \mathrm{C}_{2}-\mathrm{NiCr}$ coating underwent severe wear at high rotational speed, which is in accord with the wear rates and worn surfaces morphology in Figures $4 \mathrm{~b}$ and $6 \mathrm{~b}$, respectively. In addition, as illustrated in Figure 7e and Table 4, the maximum depth and width of the wear track of the $\mathrm{Al}_{2} \mathrm{O}_{3}-13 \% \mathrm{TiO}_{2}$ coating were about 35 and $1.48 \mathrm{~mm}$, which were the lowest values among these tribopairs. In addition, this result could indirectly explain why the friction coefficient of CF-PEEK/ $/ \mathrm{Al}_{2} \mathrm{O}_{3}-13 \% \mathrm{TiO}_{2}$ tribopair was relatively minimal under $100 \mathrm{~N}$ and $300 \mathrm{r} / \mathrm{min}$ (Figure 3). 


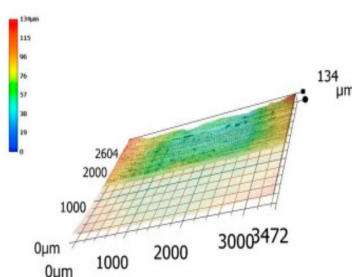

(a)

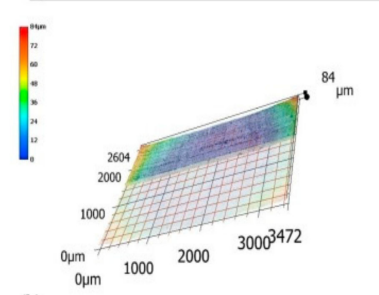

(b)

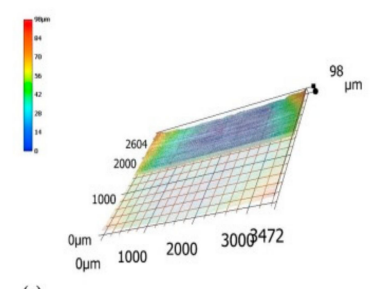

(c)

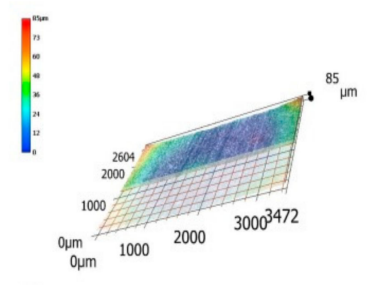

(d)

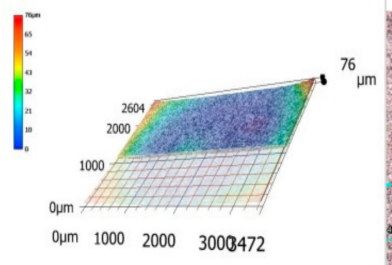

(e)
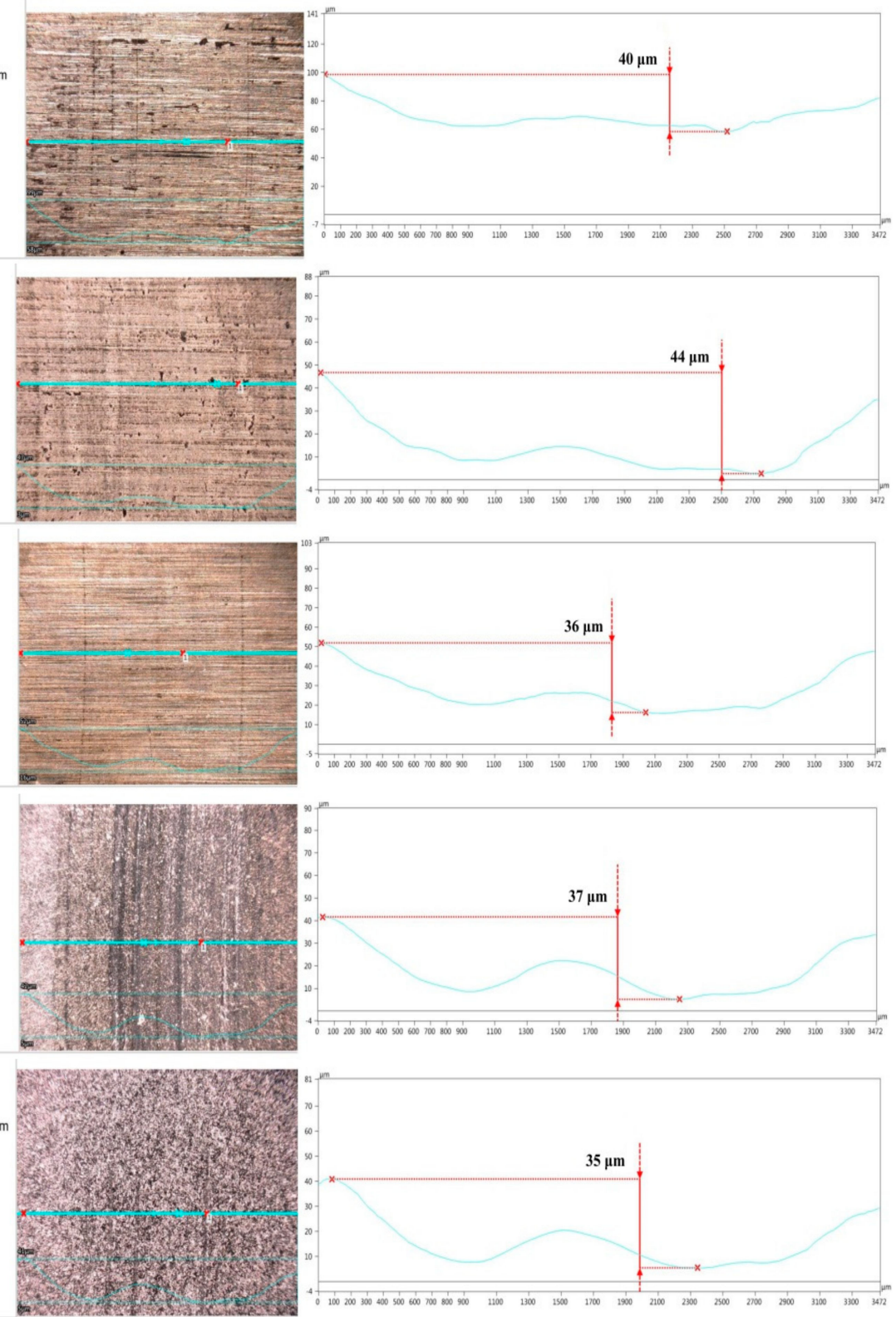

Figure 7. Worn surface scars of the lower specimens (100 N, $300 \mathrm{r} / \mathrm{min})$ : (a) $17-4 \mathrm{PH}$; (b) $\mathrm{Cr}_{3} \mathrm{C}_{2}-\mathrm{NiCr}$; (c) WC-10Co-4Cr; (d) $\mathrm{Cr}_{2} \mathrm{O}_{3}$ and (e) $\mathrm{Al}_{2} \mathrm{O}_{3}-13 \% \mathrm{TiO}_{2}$.

Table 4. Wear track results of the lower specimens (100 N, 300 r/min).

\begin{tabular}{ccc}
\hline Specimen & Wear Scar Depth $(\mu \mathbf{m})$ & Wear Scar Width $(\mu \mathbf{m})$ \\
\hline $17-4 \mathrm{PH}$ & 40 & 2194 \\
$\mathrm{Cr}_{3} \mathrm{C}_{2}-\mathrm{NiCr}$ Coating & 44 & 3041 \\
$\mathrm{WC}-10 \mathrm{Co}-4 \mathrm{Cr}$ Coating & 36 & 2002 \\
$\mathrm{Cr}_{2} \mathrm{O}_{3}$ Coating & 37 & 2291 \\
$\mathrm{Al}_{2} \mathrm{O}_{3}-13 \% \mathrm{TiO}_{2}$ Coating & 35 & 1482 \\
\hline
\end{tabular}

This is due to the fact that the $\mathrm{Al}_{2} \mathrm{O}_{3}-13 \% \mathrm{TiO}_{2}$ can react tribo-chemically with water to produce a reaction film in the sliding process. In addition, the reaction process can be described as follows: $\mathrm{Al}_{2} \mathrm{O}_{3}$ $+3 \mathrm{H}_{2} \mathrm{O}=2 \mathrm{Al}(\mathrm{OH})_{3}[15]$. As the reaction film is easily sheared randomly, a low friction coefficient and wear rate of CF-PEEK/ $/ \mathrm{Al}_{2} \mathrm{O}_{3}-13 \% \mathrm{TiO}_{2}$ tribopair can be obtained in water. However, as the CF-PEEK slid against $17-4 \mathrm{PH}, \mathrm{Cr}_{3} \mathrm{C}_{2}-\mathrm{NiCr}$, WC-10Co-4Cr and $\mathrm{Cr}_{2} \mathrm{O}_{3}$, these tribopairs could not react easily 
with water [23]. Consequently, the tribological behaviors of CF-PEEK/17-4PH, CF-PEEK/Cr ${ }_{3} \mathrm{C}_{2}-\mathrm{NiCr}$, CF-PEEK/WC-10Co-4Cr, CF-PEEK/ $/ \mathrm{Cr}_{2} \mathrm{O}_{3}$ tribopairs were worse than that of CF-PEEK/ $/ \mathrm{Al}_{2} \mathrm{O}_{3}-13 \% \mathrm{TiO}_{2}$ tribopair. In addition, to improve the tribological behaviors of tribopairs in WHAPP and for further proving the important findings in this research, the material combination of CF-PEEK/ $/ \mathrm{Al}_{2} \mathrm{O}_{3}-13 \% \mathrm{TiO}_{2}$ will be applied to the key tribopairs in the pump prototype. Moreover, it will be one of the main research topics in the future to conduct long-term experimental research on WHAPP prototype, to study its tribological performance under actual size and working conditions, and to deal with the electrochemical corrosion of friction pairs for our seawater hydraulic components [24].

\section{Conclusions}

The tribological performance of CF-PEEK composite coupled with 17-4PH stainless steel and 17-4PH coated with $\mathrm{Cr}_{3} \mathrm{C}_{2}-\mathrm{NiCr}$, WC- $10 \mathrm{Co}-4 \mathrm{Cr}, \mathrm{Cr}_{2} \mathrm{O}_{3}$ and $\mathrm{Al}_{2} \mathrm{O}_{3}-13 \% \mathrm{TiO}_{2}$ in water was comparatively investigated. By varying the rotational speed from 100 to $300 \mathrm{r} / \mathrm{min}$, it has been found that the higher speed is beneficial to improving the tribological behaviors for $17-4 \mathrm{PH}, \mathrm{WC}-10 \mathrm{Co}-4 \mathrm{Cr}, \mathrm{Cr}_{2} \mathrm{O}_{3}$ and $\mathrm{Al}_{2} \mathrm{O}_{3}-13 \% \mathrm{TiO}_{2}$ coatings, while the increase of speed makes the tribological performance of $\mathrm{Cr}_{3} \mathrm{C}_{2}-\mathrm{NiCr}$ coating worse, and the $\mathrm{Cr}_{3} \mathrm{C}_{2}-\mathrm{NiCr}$ coating could be damaged under $100 \mathrm{~N}$ and $300 \mathrm{r} / \mathrm{min}$ lubricated with water. Proper increase of the surface hardness of $17-4 \mathrm{PH}$ by cermet coatings can improve the wear resistance of the tribopairs in water. However, the large hardness difference between the CF-PEEK and cermet coatings could accelerate the wear of the soft CF-PEEK. The CF-PEEK $/ \mathrm{Al}_{2} \mathrm{O}_{3}-13 \% \mathrm{TiO}_{2}$ material combination presents the best friction and wear performance among the tested five combinations under water lubrication conditions. The proposed CF-PEEK $/ \mathrm{Al}_{2} \mathrm{O}_{3}-13 \% \mathrm{TiO}_{2}$ tribopair has potential to replace the existing material combination of stainless steel and PEEK, and the working performance of the water hydraulic piston pump will be further improved.

Author Contributions: S.N. made the conception of the work and revised the manuscript critically for tribological analysis; F.L. performed the experiments and analyzed the data; H.J. carried out experimental design and wrote the manuscript; F.Y. wrote the literature review and other parts of the content.

Funding: The authors would like to thank the Beijing Natural Science Foundation (Grant Nos. 3182003 and 1184012), National Natural Science Foundation of China (Grant Nos. 51705008 and 11572012), Beijing Municipal Science and Technology Project (Grant Nos. KM201810005014 and KM201910005033), International Research Cooperation Seed Fund of Beijing University of Technology (Grant No. 2018B17) and CSIC Key Laboratory of Thermal Power Technology Open Foundation (Grant No. TPL2017AB010) for their funding for this research.

Acknowledgments: We are grateful to Xiaoyan Song and Haibin Wang for offering necessary assistance of the HVOF technique, and the editors and the anonymous reviewers for their insightful comments and suggestions.

Conflicts of Interest: The authors declare no conflict of interest.

\section{References}

1. Yang, H.Y.; Pan, M. Engineering research in fluid power: A review. J. Zhejiang Univ-Sci. A 2015, 16, 427-442. [CrossRef]

2. Zhu, Y.; Chen, X.; Zou, J.; Yang, H. A study on the influence of surface topography on the low-speed tribological performance of port plates in axial piston pumps. Wear 2015, 338-339, 406-417. [CrossRef]

3. Zhang, J.H.; Chen, Y.; Xu, B.; Chao, Q.; Zhu, Y.; Huang, X.C. Effect of surface texture on wear reduction of the tilting cylinder and the valve plate for a high-speed electro-hydrostatic actuator pump. Wear 2018, 414-415, 68-78. [CrossRef]

4. Ye, S.G.; Zhang, J.H.; Xu, B.; Zhu, S.Q.; Xiang, J.W.; Tang, H.S. Theoretical investigation of the contributions of the excitation forces to the vibration of an axial piston pump. Mech. Syst. Signal. Process. 2019, 129, 201-217. [CrossRef]

5. Drabløs, L.S. Testing of DanfossAPP1.0-2.2 with APP pumps as water hydraulic motors for energy recovery. Desalination 2005, 183, 41-54. [CrossRef]

6. Yin, F.L.; Nie, S.L.; Ji, H.; Huang, Y.Q. Non-probabilistic reliability analysis and design optimization for valve-port plate pair of seawater hydraulic pump for underwater apparatus. Ocean Eng. 2018, 163, 337-347. [CrossRef] 
7. Lim, G.H.; Chua, P.S.K.; He, Y.B. Modern water hydraulics-the new energy-transmission technology in fluid power. Appl. Energy 2003, 76, 239-246. [CrossRef]

8. Majdič, F.; Pezdirnik, J.; Kalin, M. Experimental validation of the lifetime performance of a proportional 4/3 hydraulic valve operating in water. Tribol. Int. 2011, 44, 2013-2021. [CrossRef]

9. Mohanty, M.; Smith, R.W.; Bonte, M.D.; Celis, J.P.; Lugscheider, E. Sliding wear behavior of thermally sprayed 75/25 $\mathrm{Cr}_{3} \mathrm{C}_{2} / \mathrm{NiCr}$ wear resistant coatings. Wear 1996, 198, 251-266. [CrossRef]

10. Wei, J.; Xue, Q. The friction and wear properties of $\mathrm{Cr}_{2} \mathrm{O}_{3}$ coating with aqueous lubrication. Wear 1996, 199, 157-159. [CrossRef]

11. Zavareh, M.A.; Ahmed, A.D.M.S.; Bushroa, B.R.; Wan, J.B. The tribological and electrochemical behavior of HVOF-sprayed $\mathrm{Cr}_{3} \mathrm{C}_{2}-\mathrm{NiCr}$ ceramic coating on carbon steel. Ceram. Int. 2015, 41, 5387-5396. [CrossRef]

12. Huang, W.; Xu, Y.; Zheng, Y.; Wang, X.L. The tribological performance of Ti (C, N) -based cermet sliding against $\mathrm{Si}_{3} \mathrm{~N}_{4}$ in water. Wear 2011, 270, 682-687. [CrossRef]

13. Wu, D.F.; Liu, Y.S.; Li, D.L.; Zhao, X.F.; Ren, X.J. The applicability of WC $-10 \mathrm{Co}-4 \mathrm{Cr} / \mathrm{Si}_{3} \mathrm{~N}_{4}$ tribopair to the different natural waters. Int. J. Refract. Met. Hard Mater. 2016, 54, 19-26. [CrossRef]

14. Wu, D.F.; Liu, Y.S.; Zhao, X.F.; Li, D.L.; Ren, X.J. The tribological behaviors of different mass ratio $\mathrm{Al}_{2} \mathrm{O}_{3}-\mathrm{TiO}_{2}$ coatings in water lubrication sliding against $\mathrm{Si}_{3} \mathrm{~N}_{4}$. Tribol. Trans. 2016, 59, 352-362. [CrossRef]

15. Wang, C.T.; Ye, Y.W.; Guan, X.Y.; Hu, J.M.; Wang, X.; Li, J.L. An analysis of tribological performance on $\mathrm{Cr} / \mathrm{GLC}$ film coupling with $\mathrm{Si}_{3} \mathrm{~N}_{4}, \mathrm{SiC}, \mathrm{WC}, \mathrm{Al}_{2} \mathrm{O}_{3}$ and $\mathrm{ZrO}_{2}$ in seawater. Tribol. Int. 2016, 96, 77-86. [CrossRef]

16. Strmčnik, E.; Majdič, F.; Kalin, M. Water-lubricated behaviour of AISI 440C stainless steel and a DLC coating for an orbital hydraulic motor application. Tribol. Int. 2019, 131, 128-136. [CrossRef]

17. Qiu, B.J.; Zhao, J.Y.; Man, J.X. Comparative study of materials for friction pairs in a new high water-based hydraulic motor with low speed and high pressure. Ind. Lubr. Tribol. 2019, 71, 164-172. [CrossRef]

18. Zhu, S.Y.J.; Ma, Q.; Tan, H.; Cheng, J.; Yu, Y.; Qiao, Z.H.; Yang, J. Tribological behavior of nickel aluminum-silver solid-lubricating alloy coupled with different tribo-pairs lubricated by seawater. Tribol. Int. 2019, 131, 158-166. [CrossRef]

19. Chen, B.B.; Wang, J.Z.; Yan, F.Y. Comparative investigation on the tribological behaviors of CF/PEEK composites under sea water lubrication. Tribol. Int. 2012, 52, 158-166. [CrossRef]

20. Wang, Z.Q.; Gao, D.R. Comparative investigation on the tribological behavior of reinforced plastic composite under natural seawater lubrication. Mater. Des. 2013, 51, 983-988. [CrossRef]

21. Dong, W.T.; Nie, S.L.; Zhang, A.Q. Tribological behavior of PEEK filled with CF/PTFE/Graphite sliding against stainless steel surface under water lubrication. Proc. Inst. Mech. Eng. J-J. Eng. 2013, 227, 1129-1137. [CrossRef]

22. Zhang, Z.H.; Nie, S.L.; Yuan, S.H.; Liao, W.J. Comparative evaluation of tribological characteristics of $\mathrm{CF} / \mathrm{PEEK}$ and CF/PTFE/Graphite filled PEEK sliding against AISI630 steel for seawater hydraulic piston pumps/motor. Tribol. Trans. 2015, 58, 1096-1104. [CrossRef]

23. Hochstrasser, S.; Mueller, Y.; Latkoczy, C.; Virtanen, S.; Schmutz, P. Analytical characterization of the corrosion mechanisms of WC-Co by electrochemical methods and inductively coupled plasma mass spectroscopy. Corros. Sci. 2007, 49, 2002-2020. [CrossRef]

24. Zhang, J.; Su, X.L.; Shan, L.; Liu, Y.; Zhang, P.; Jia, Y. Preparation and tribocorrosion performance of CrCN coatings in artificial seawater on different substrates with different bias voltages. Ceram. Int. 2019, 45, 9901-9911. [CrossRef]

(C) 2019 by the authors. Licensee MDPI, Basel, Switzerland. This article is an open access article distributed under the terms and conditions of the Creative Commons Attribution (CC BY) license (http://creativecommons.org/licenses/by/4.0/). 